\title{
TRANSFORMACIJSKI IZZIVI ZA VARNOST NA SLOVENSKEM MORJU
}

\section{TRANSFORMATION CHALLENGES TO SAFETY AND SECURITY AT SLOVENIAN SEA}

Povzetek Sodobno varnostno okolje na morju je čedalje bolj kompleksno, grožnje pa so nepredvidljive in lahko povzročijo dolgotrajne posledice. Klasična in birokratska organizacija subjektov varnosti na Slovenskem morju ne bo mogla dolgo slediti varnostnim izzivom. Ti zahtevajo nove pristope in oblike organiziranja zaradi povečanja zmogljivosti in učinkovitosti delovanja ter racionalizacije porabe javnih sredstev. Vsestranski pristop, sodelovanje in koordinacija ali pa celo integracija različnih služb varnosti na morju so nekateri odgovori na vprašanja sodobnega varnostnega okolja.

Ključne Pomorska varnost, vsestranski pristop, koordinacija, integracija.

besede

Abstract Modern security environment at sea is increasingly complex, while threats are unpredictable and can have long-term consequences. The classic and bureaucratic way of organizing different safety and security services responsible for Slovenian sea will not be able to keep up with modern security challenges for a long time, since these require new approaches and forms of organization. The main aim is to increase the capabilities, efficiency and effectiveness of operations and at the same time to rationalize the use of public finance. Comprehensive approach, cooperation and coordination or even integration of various sea safety and security services may be the answers to the modern security environment.

Key words Maritime safety and security, comprehensive approach, coordination, integration. 
Introduction The sea is of major economic, political and military importance to Slovenia. The Port of Koper with its position in the far north of the Adriatic Sea provides optimum conditions for economic flourishing of the Slovenian coast and the inland of the country. Slovenian sea also functions as a sea gate for several Central European countries, with the Port of Koper being the leading transhipment port for Austria in 2010, for 33\% of all Austrian goods shipped by sea (http://www.verkehr. co.at, 10.06.2011). It is important that Slovenia develops own means for its protection, either independently or in cooperation with the Alliance. Can the existing safety and security organization on Slovenian sea successfully meet the challenges of time? Is the public spending for sea safety and security cost effective? Does Slovenia have adequate material and personnel resources? Is Slovenia developing sea defence and security concepts? Those are just some of the professional issues to be addressed as part of the future transformation process in the field of defence and the wider security. However, the first issue to be raised is the existence of political will in Slovenia for fundamental reforms to be able to reflect on transformation of defence and the military as known in Western countries, and of the entire security sector as part of complete renovation of public administration. Podbregar argues that the environment, and Slovenian politics in particular, has a very opportunistic approach towards the Slovenian Armed Forces and is only rarely prepared to address its development needs being the ultimate constant factor of any military.

In the past, the Slovenian Armed Forces successfully responded to transition challenges and implemented the relevant objectives in several areas. Worth mentioning is particularly the efficient organizational downsizing and personnel reductions, which were aimed at enhancing operational effectiveness while maintaining the core of forces and capabilities which would efficiently meet the challenges of contemporary security environment in cooperation with the allies (Šteiner, 2010). Transition was also successfully managed by maritime forces currently representing approximately $1.3 \%$ of the entire Slovenian Armed Forces' structure. From scratch, during the time of Slovenian war of independence in 1991, an enviable security entity has started to emerge on Slovenian sea to evolve after 20 years into the $430^{\text {th }}$ Naval Division. The unit has undergone several reorganization stages in accordance with the Slovenian Armed Forces' (SAF) development concepts and in line with the challenges of security environment. The last reorganization took place when the unit acquired a new multi-purpose boat TRIGLAV11.

Contemporary threats at sea are far more unpredictable and intense than those 20 years ago, as well as long-lasting in terms of their impact potentially causing damage that cannot be repaired for years if not decades. It is therefore, from the security perspective, important to develop such capabilities and organization at sea to ensure timely awareness of threats and, at the same time, efficient response to suppress or remove risks. One the other hand, one should be aware that modern capabilities cannot be developed exclusively for one type of threats or protection of one's own »little garden «, but should rather involve multi-purpose forces capable of conducting the full-range of operations in the framework of comprehensive approach to safety 
and security at sea. According to Podbregar, we are entering the period of highly trained, competent leaders and the period lacking precious coordination time for the resolution of threats and crises (Podbregar, 2011). In short, there is a need for standing forces, organized into a flexible structure with clearly defined procedures, equipped with advanced technology, integrated, and manned with qualified staff capable of cooperation at home and beyond national borders.

\section{THE SEA AND SECURITY CHALLENGES}

\subsection{Complexity of global security environment}

Peace, security, stability and development are becoming increasingly interconnected, and demand enhanced cooperation and coordination of countries and international organizations as well as other non-state actors in various fields. In the future, the international security environment will be challenged above all by climate change, unfavourable global demographic, financial, economic and social movements, limited natural and other strategic resources, uncontrolled trade in sensitive materials and services, the deepening differences between the rich and poor parts of the world, crisis areas, emergence of new forms and nature of conflicts as well as various globalisation effects. A permanent source of threats is also natural and other disasters, the intensity and frequency of which are increasing as a result of climate change and environment overburdening.

\subsection{Contemporary security threats at sea and appropriate response}

Sea routes are still cheapest and, hence, massively exploited, but also highly vulnerable to modern threats. In terms of their scope, threats at sea can be divided into national, supranational and global, and into military, non-military and natural disasters in terms of their origin. According to current assessments, military threats are at their minimum, but can still not be ignored. The division line between measures and the necessary deterrent forces is no longer clear. The sea is turning into a man's living environment, the navigation space for huge oil tankers, supper passenger and other ships accommodating over 5000 people on board, which can become highly attractive targets for pirates and terrorists.

NATO regards terrorism as one of the key threats of modern era, which was the main reason for launching the NATO-led operation Active Endeavour in the Mediterranean. As the only NATO-led operation conducted so far under Article 5 of the Washington Treaty, the operation should serve as the sign of solidarity to the US in the aftermath of 11 September 2001 terrorist attacks (http://www.manp. nato.int/ operations/Active Endeavour/, 16.05.2011). For the time being, Slovenia has no maritime forces available for participation in the operation, but can make an important contribution in the field of intelligence by sharing the information with the allies on potential sea threats. The «need to know « principle applied recently is now being transformed into the $»$ need to share « principle (Maritime security: NATO and EU roles and coordination, http://www.nato-pa.int, 02.06.2011). 
The modern form of piracy emerged in the early $21^{\text {st }}$ century in the Indian Ocean in the vicinity of the Somali Horn. Nowadays, Somali pirates use primitive vessels and weapons for disturbing the movement of large cargo ships, crew kidnapping, and enforcing high bribes. Despite their simple tactics, they have caused the rise of insurance premium on sea cargo and inflicted large economic damage. With the European Union counter-piracy operation ATALANTA ${ }^{1}$ in the Gulf of Aden, the international community has succeeded in reducing the number of kidnapped ships since 2008 despite the enlarged operational area of pirates. The area of piracy operations is expanding far into the Indian Ocean, up to India and the Arab's Gulf as well as along the south-eastern coast of Africa (Žabkar, 2011). NATO participates in the counter-piracy operation ${ }^{2}$ with the Maritime Security Centre and military vessels carrying out control and monitoring of ships at sea.

Europe has become a target for many economic and forced migrants, many of whom arrive by sea. In Europe, North-African migrants represent currently one of the biggest migrant groups. To them, European countries are promised lands (Italy - Lampedusa). The continuous increase of their numbers may have an impact on stability in the wider area of South Europe. The decision reached by the Italian Government in April 2011 to grant African migrants temporary European visas has triggered a strong reaction by France regarding the implementation of stricter control measures on the border with Italy. The problem should definitely be addressed comprehensively within the international community, i.e. the EU in this particular case. Slovenia is regarded as the country of destination by many migrants coming mostly from the Balkans' countries, which emerged after the dissolution of the former common state of Yugoslavia. The trends in migration flows are changing and depend upon the circumstances in the region and the economy in Slovenia. Migrants from the Balkans usually do not use sea routes, as land routes are far more convenient for them. The likelihood of an uncontrollable outbreak and spreading of contagious diseases additionally increases migration of the population, natural disasters and terrorism.

Modern society depends heavily on uninterrupted and reliable functioning of information systems. Any system malfunctions may therefore represent a serious threat to the activity of public and private sectors in general, notably to the principal functions of the state and society. Owing to the diversity of information and communication systems, the free cyber space and problems associated with its control, the spreading of various forms of computer crime at sea, especially cyber attacks against governmental and non-governmental entities which cannot be limited in space and time, are also likely.

\footnotetext{
ATALANTA is the European Union's first naval operation. It was launched on the basis of UN Security Council Resolutions 1814, 1816, 1838 in 1846 adopted in 2008, Resolution 1918 adopted in 2009 and Resolution 1970 adopted in 2010. http://www.eunavfor.eu/ (27.04.2011).

2 Since 9 October 2008, NATO has participated in the fight against piracy off the Horn of Africa as part of Operation Allied Provider ensuring military escort for convoys of merchant ships. On 17 August 2009, Operation Ocean Shield was launched with the same mandate as the previous one and even more comprehensive approach by preparing domestic capabilities for the fight against piracy. http://www.manw.nato. int/page_operation_ocean_shield.aspx (18.05.2011).
} 
Earthquakes, volcanic eruptions, floods, storms and fires have accompanied mankind since its very beginnings. Nowadays, we are also witnessing other disasters, such as air pollution, spills of hazardous materials at sea, nuclear accidents etc., which are all the consequences of man's impact on nature. The impact is multi-layered, ranging from economic, environmental, demographic and also to political domains. The economic logic of environmental effect, climate change and disregard for past experiences intensify the adverse impact of natural disasters. The entire northern Adriatic Sea is a gulf-type sea, where the negative influence of individual factors on its quality is bigger than in deeper and high seas. The biggest potential risk of pollution with catastrophic dimensions comes from big tankers navigating $3-5 \mathrm{~km}$ off the Slovenian coast, and from big off-shore warehouses for oil, oil derivatives and chemicals. Apart from stranding, collision, fires and explosions on ships, there is also a high risk of spills during loading and unloading of ships' cargo or fuel. As there is a strong likelihood of such pollution, prevention measures must be strictly enforced. This demands a well-organised and equipped service which will ensure effective sea protection either independently or as part of a joint national service in charge of sea security in its largest sense.

\section{ORGANIZATION OF SECURITY SERVICES ON SLOVENIAN SEA}

\subsection{The basis for the organization of security services at sea}

Slovenia's maritime orientation was already recognized at the first democratic Assembly of the Republic of Slovenia on 7 March 1991 with the adoption of the Resolution on the Maritime Orientation of the Republic of Slovenia, which preserves the advantage of the exit to the Adriatic Sea. The resolution, among other things, states a clear intention of the Republic of Slovenia to pursue maritime-oriented economic and development policy. To this end, Slovenia will support the development of the Port of Koper and, through the port-based transit and land traffic, further the enlargement of permanent sea routes, protect the public interest in port operations, pilotage, towing, rescue and passenger maritime transport, provide conditions for the development of cargo shipping which will be able to do business in the global market, systematically promote acquisition of food and other products from sea, and ensure legal arrangements in compliance with international rules, and will therefore (Resolution on Maritime Orientation of the Republic of Slovenia, Official Gazette of the Republic of Slovenia, no.10/91):

a) Set up a service or services in charge of control of the sea and the coast in terms of security, navigation, ecology, sanitary-health and fiscal aspects;

b) Regulate sea border control;

c) Reach comprehensive agreement with its two maritime neighbours on maritime navigation routes and regimes as well as fishing areas in the Adriatic Sea.

Based on resolution stipulations it can be concluded that the provision of security, safe maritime transport and protection of sea are in the national interest of the Republic of Slovenia. Geršak maintains that Slovenia is faced with challenges 
and has to be prepared to counter both conventional and the increasing number of asymmetric threats from and at sea. For this reason, the national security system of the Republic of Slovenia must take into consideration military and non-military sources of threats in national security, irrespective of their origin. Various sources of threat are interconnected. Occurrences in a specific area of society may also have an impact on the other, thereby increasing the threat level. Such threat concepts demand high adaptability of the national security system of the Republic of Slovenia. It is also important for Slovenia's strategic security environment to constantly monitor, analyze and make authentic assessments, bearing in mind at the same time that the causes of conflict situations in the international community can only be managed through enhanced cooperation and joint operation (Geršak, 2008).

\subsection{Capabilities for providing security on Slovenian sea}

Threat deterrence capabilities are within the national security system of the Republic of Slovenia connected mainly to sub-systems of traffic, internal and defence security. Moreover, all other sub-systems, such as systems pertaining to the environment, economy, finance, protection and rescue, and education, which through their operation support the effectiveness of primary services on Slovenian sea as well as the wider international community, should also be taken into account. Sea securityrelated tasks in the widest sense of the word are currently being performed by the following services: Maritime police, Port state control, $430^{\text {th }}$ Naval division, Service for protection of coastal sea, Regional office of the Administration of the Republic of Slovenia for Civil Protection and Disaster Relief, Service for protection of sea of the Port of Koper, Koper customs office and Marine biology station. These services are organized as government agencies or as part of the Port of Koper Company. A simple analysis shows that there are 31 vessels altogether available for their use, which are mainly small and cannot perform tasks under rough sea conditions when the need for providing security usually arises (Žnidar, 2011). The issue of rationality in equipping sea security services with vessels of limited capacity is well founded. Deriving from the fact that Slovenia, on the one hand, is a relatively small maritime country, and that the occurrence of modern, increasingly unpredictable threats at sea, on the other hand, demands continuous situation monitoring and rapid and efficient responsiveness, the efficiency of security services' fragmentation on Slovenian sea becomes highly relevant.

\section{POSSIBLE APPROACHES TO SEA SECURITY ORGANIZATION}

\subsection{Comprehensive ${ }^{3}$ approach to providing security at sea}

Against the background of security threats and threat complexity in the future it can be concluded that individual operations of security services anywhere in the world, and similarly on Slovenian sea, will not bring the desired results in the future, i.e. it will be neither effective nor efficient or even successful. There will be a need for

3 Comprehensive Approach as a term has two equivalents in Slovene resources and may denote completeness and comprehensiveness. 
cooperation, exchange of information, coordination and mutual assistance. According to Androjna, Slovenia has embraced a two-tier approach involving enhanced regional and multinational cooperation on the one hand, and better solutions and interagency coordination on the national level on the other (Androjna, 2010).

One of the possible modus operandi and greater efficiency of sea security services is embodied in the comprehensive approach, which can play a decisive role in ensuring success of modern operations, whose character is becoming increasingly civilianmilitary rather than military. This approach involves joint operational and mission planning and preparation, regular mutual coordination, consultation, and operation of all military and non-military actors in line with the contemporary approach of crisis management (US JFCOM, 2008).

The key areas of comprehensive approach are: joint planning and operations, lessons learned, close cooperation with non-military actors, public diplomacy, and stabilisation and reconstruction. Operational planning itself demands continued gathering of information and corrections of plans up to the conclusion of an operation. Amendments must be based on prudent monitoring and analysis of the impact of one's activities. The planning part should clearly define the desired impact of individual activities enabling the defined operational objectives. In addition to planning specific activities, their desired objectives, the possible impact and desirability should also be assessed. This can be achieved though continuous gathering, supplementing and analyzing of all relevant information before, during, and also after the operation or mission. It should also be mentioned that the world is flooded with data and messages, various perceptions of data capture, and that only a limited number of them are processed as information. Quality and comprehensible information of reasonable size can be key to greater efficiency of the comprehensive approach in providing security at sea. In addition to the information exchange, security at sea based on comprehensive approach also demands confidence among the stakeholders. The advantage of the comprehensive approach in providing security at Slovenian sea derives from the fact that no legislative changes and additional financial investment are required to increase its efficiency. On the other hand, it is necessary to clearly define the objectives, to master extensive knowledge and information, to ensure uniform understanding of standards, and to, above all, create the atmosphere stimulating the will and needs of all actors for participation in the processes leading to the fulfilment of desired objectives. The biggest disadvantage of such an approach still remains the need for developing a large body of security services, which requires major investment into equipment and training as well as standardization of processes and equipment on the one, and preparedness of services for cooperation on the other hand.

\subsection{Coordination of sea services}

On an initiative by a member of the RS National Assembly, an interagency working group was established in 2002, which explored the possibility of establishing an independent joint service for sea-related tasks or a coordination body dealing 
with coordination of all security services on Slovenian sea. In accordance with an analysis based on $\mathrm{SWOT}^{4}$ method, the group submitted a recommendation to the Government in 2003 to set up coordination of sea services, which was formalized with the Government decision of 31 August $2006^{5}$. Coordination is carried out on two levels: on strategic level as Sea service coordination, and on operational level as Operational maritime coordination. Sea service coordination has the following members:

a) Ministry of Infrastructure, Slovenian Maritime Administration;

b) Ministry of the Interior, Police, Police Directorate Koper;

c) Ministry of the Environment and Spatial Planning, Environmental Agency;

d) Ministry of Finance, Customs Administration of the Republic of Slovenia, Koper Customs Directorate;

e) Ministry of Defence, Slovenian Armed Forces, Force Command;

f) Ministry of Defence, RS Administration for Civil Protection and Disaster Relief;

g) Ministry of Foreign Affairs, European Affairs and Bilateral Political Relations Directorate;

h) Ministry of Agriculture, Forestry and Food, Agriculture, Forestry and Food Inspectorate of the Republic of Slovenia.

Operational coordination and the actual implementation of tasks related to Sea service coordination is carried out through the Operational maritime coordination (OMC) consisting of:

a) Slovenian Maritime Administration, Maritime Division - Harbour Master's Office;

b) Police Directorate Koper, Maritime Police Station Koper;

c) Koper Customs Directorate, Piran Branch Office and Port of Koper Branch Office;

d) Environmental Agency, Adriatic Sea Area Division;

e) Agriculture, Forestry and Food Inspectorate of the Republic of Slovenia, Hunting and Fisheries Inspection Service;

f) Slovenian Armed Forces, Force Command, $430^{\text {th }}$ Naval Division;

g) Administration of the Republic of Slovenia for Civil Protection and Disaster Relief, Koper Branch Office.

The tasks of Sea service coordination and Operational maritime coordination involve primarily:

h) Management of common sea issues;

i) Processing and analysis of sea situation;

j) Recommendations for the improvement of sea situation to achieve better efficiency and expeditious accomplishment of tasks as well as rational use of available technical means, coordination of work among individual bodies involved in Sea service coordination and Operational maritime coordination;

k) Cooperation with other bodies dealing with activities at sea;

1) Information services for competent authorities dealing with sea security issues;

\footnotetext{
4 Advantages/weaknesses (internal factors), opportunities/risks (external factors)
}

5 Decision by the Government no. 37300-2/2006/8 dated 31.08.2006. 
m) Development and promotion of activities for enhanced safety and security, and efficient rescue and search operations at sea.

Geršak mentions that operational coordination meetings are recorded in the minutes and that some key decisions were made (Geršak, 2008), as follows:

a) The Ministry of the Interior and the Ministry of Transport shall draft an agreement on the integration of police maritime radar with automatic identification system of the Slovenian Maritime Administration into a joint maritime traffic surveillance system;

b) A proposal for the establishment of maritime meteorology and hydrology service should be initiated and submitted to the Ministry of the Environment in order to draft documents for further discussion at the RS Government level;

c) The inspector of the fishery sector should gather the required information on the access of Slovenian Maritime Administration and Police Directorate Koper to the fishing vessel monitoring system;

d) A uniform maritime information system (UMIS) should be set up combining the data from the system of individual government bodies - members of sea coordination services and European Maritime Information System (SafeSeaNet) ${ }^{6}$.

According to the opinion of Head of Koper Harbour Master's Office, Davorin Fantulin, the various bodies of government agencies function well, even so well that Slovenia's example was followed by the EU in the establishment of the common European coast guard. As the systems and the legal basis for maritime monitoring are far too different in individual countries to have a common denominator, it was decided to create sea service coordination similar to the one established in Slovenia. The advantages of coordination operations can have an immediate effect reflected in formal cooperation and resolution of security issues and sea safety at joint meetings, regular mutual notification and acceptance of initiatives for improved sea security. The analysis of meetings shows that some significant initiatives have been adopted with a potential to increase the efficiency of all sea security services. The majority of sea services is satisfied with the established coordination or simply accepts the current situation. The key issue of whether the existing organization is sufficiently efficient and effective remains, however, unresolved. A mention should be made here, though, that the equipment and asset maintenance processes as well as personnel training are carried out entirely separate in individual government agencies, which influences both the cost and standardization of equipment as well as efficiency of joint sea operations.

\footnotetext{
SafeSeaNet is an information system set up by the European Union to provide quick and efficient data exchange among maritime authorities of member states. The system enables improved response of competent authorities during disasters and emergency situations at sea, including search and rescue, as it enables improved monitoring of ships during movements and in ports, helps improve the efficiency of port logistics and response time during search and rescue operations as well as facilitates maritime safety, protection of environment against and during pollution of sea, and supports other sea services, such as the customs, police, military etc.
} 


\subsection{Integration of sea security services}

The rapidly changing strategic environment and modern sources of threat necessitate not only information exchange and coordination, but also cooperation.

The establishment of a joint sea service, the Coast guard of the Republic of Slovenia, was a topic of discussions by the Maritime Board of the Republic Assembly as early as in 1991 and 1992, which was then abandoned. Soon after that the first maritime unit of independent Slovenia was established, the $430^{\text {th }}$ Maritime Detachment, the predecessor of the current $430^{\text {th }}$ Maritime Division. In 2002, the RS Parliament member Aurelio Juri re-launched the initiative for the establishment of a working group to explore possible forms of sea service organization. The governmental working group finalized its work in early 2003 and submitted a proposal to the RS Government with the following conclusions (http://slovensko-morje.net/sm_staro/ obalna_straza.htm, 20.06.2011):

a) Sea services are poorly equipped;

b) Services are understaffed;

c) The legislation regulates the powers, obligations and organization of individual government agencies, which allows for a relatively autonomous operations of services;

d) The merging of services would require changes to applicable laws of individual agencies or development of new legislation on sea security;

e) The merging of structures at that time could lead to reduced efficiency or even disbandment of services;

f) Sea security would be best provided through coordination of services.

The majority of the working group members shared the opinion that the merging of sea services was a political project and solution for the Maritime police, which had technical problems with its vessels. Various interests of ministries should also be mentioned in this regard, in particular the issue of assigning the leading role in the integrated structure of sea services and the associated finance control. In August 2010, the Parliament member Franco Juri re-launched the initiative on the establishment of the coast guard as a joint service on Slovenian sea, following the procurement of the multi-purpose boat Triglav and the discussions on the Resolution of the long-term programme of equipping the Slovenian Armed Forces up to 2025, which, however, evoked no serious discussion. Despite several political initiatives in the past, the initiatives stemming from the years 2002 and 2003 stimulated the widest professional debate so far. Nowadays, the situation is changed in many different ways; for one thing, the services' personnel and material resources have improved and consolidated in terms of their organization. The nuclei of experts have been created to successfully manage sea security processes. At the same time, the need for more efficient and rational organization of sea security organization developed, possibly involving integration of services, which can be linked to at least three reasons:

a) There is a big number of small government sea services differing in their organization, management and equipment, particularly in terms of their vessels. 
b) Despite the big number of vessels, these vessels are mainly small and have limited capabilities to operate under difficult conditions.

c) The country is faced with a severe economic crisis diminishing national stability and already reflected in the security system, notably in the defence sub-system and the Slovenian Armed Forces.

This can also be the time for more prudent reflections and substantial security and defence reforms, including the field of security on Slovenian sea. Moreover, it should be assessed whether today the integrated structure of security services on Slovenian sea would ensure better efficiency and effectiveness, resulting at the same time in greater operational efficiency. In this regard, positive experiences and conclusions of the 2009 Strategic defence review and reform experiences of international security sectors could be applied, in particular NATO-related experiences from the transformation of its armed forces and NATO structure as a whole. A starting point for the integration of various government agencies responsible for security on Slovenian sea could also be a new concept of joint capabilities and target forces without interference with administrative bodies and their sea powers, at the same time facilitating creation of joint capabilities under joint leadership. This would also entail the definition of the legal basis for operations and relations among administrative bodies and joint capabilities functioning as in the executive role. The advantages of such integrated structure would be manifold:

a) The objectives of ensuring efficient security of all people and material means on sea and maintenance of clean sea would be put in the foreground;

b) Integrated capabilities would be managed jointly which would simplify the management system, consequently resulting in better decision making efficiency;

c) A smaller number of more efficient vessels would be needed.

d) The vessels would be standardized, thereby allowing for more efficient management and rational maintenance, or, in short, establishment of integrated logistics;

e) The education and training system for maritime staff would be simplified and unified, thereby resulting in higher quality of training programmes and personnel;

f) Greater operational efficiency, especially round-the-clock operation according to the $7 / 24^{7}$ principle, would be ensured thus contributing to better control of the maritime domain (including maritime border) and readiness level for rescue at sea. A joint service would permit planning of operational cycles and continual operational capability of vessels.

g) Minimum investment would ensure infrastructure for all vessels. At present, the vessels are moored at various berths and under various conditions. The high berthing rent they pay comes from taxpayers' money;

h) A unified maritime operations centre would be set up at sea facilitating simple and rational links with sensors (radars, AIS, sonars, night vision devices etc.) and weapon systems. 
Integrated structures, however, should not be evaluated solely for their positive characteristics but also with reference to their disadvantages and weak points, in particular:

a) The legal basis requiring political consensus. Previous experiences show that reaching a consensus can be very difficult, even on matters of key national interest;

b) Possible disagreement among individual ministries about responsibility and authority over managing integrated capabilities could therefore be resolved through an autonomous government service or through appointment of one of the agencies for procurement and maintenance of assets and training. According to relevant past experiences, the Ministry of Defence has developed a good system;

c) The initial negative impact on sea operations due to the fact that the equipment and standards of personnel qualifications differ significantly. Through prudent merging of capabilities and planned personnel training the impact could be reduced;

d) Orientation towards peacetime tasks and along with this a strong likelihood of reduced military capabilities at sea. The issue of whether the military would fit into such integrated structure is therefore logical. Experiences from the world and home as well show that the navies have a special status and also tasks going beyond the internal affairs making them a strong element of the country's foreign policy.

Conclusion Slovenia belongs to one of the smaller maritime countries with a total of $46,6 \mathrm{~km}$ of the coastline, the sea covering an area of approximately $180 \mathrm{~m}^{2}$ and the international port of Koper in the Gulf of Trieste in the northern part of the Adriatic Sea stretching deepest into Central Europe. The Gulf of Trieste as a relatively closed gulf with shallow sea provides relatively limited navigation possibilities for larger vessels, with, however, more than 5000 of them navigating in this area annually. With the classic military threats at sea having almost disappeared, new and more intense threats are emerging, such as the weapons of mass destruction, terrorism, piracy, oil wells, tankers, nuclear technology, gas terminals etc. The development of modern technology is so rapid and all-encompassing in spite of high security standards that standards cannot be met, which can have major and far-reaching consequences for the environment and people. On the other hand, a large portion of the world's population is not in position to keep up with the swift progress, resulting in new forms of organized crime and shaped in its most cruel form as terrorism against the civilian population. The international law of the sea stipulates the rights and obligations through conventions, although practice shows that not everything can be resolved through rules. It would be wrong to think that contemporary security threats at sea cannot be resolved; on the contrary, the constantly and rapidly changeable security environment demands a flexible and comprehensive approach, and ongoing coordination of interests. This should involve participation of all actors, both governmental and non-governmental. As a maritime country, Slovenia is aware of security challenges and threats at sea, which is also reflected in its politics and efforts towards establishing conditions for the development of the naval domain, 
notably through the adoption of legal documents and programmes, support of the development of naval units and sea security. At the same time, active participation of navy professionals contributes to successful management and implementation of projects in this area of work. Security of the Slovenian sea represents one of the major areas of activity, as secure and stable sea situation is of great advantage to the development of the maritime economy. On Slovenian sea, this includes formalized coordination of sea services functioning both on operational and strategic levels. In the past, that was a suitable form for cooperation and resolution of sea security issues, however, with no regard to the measurement of effectiveness and operational efficiency. The reform of security sector including the transformation of defence would therefore represent a big challenge for all security services operating on Slovenian sea. Foreign experiences, especially those of the US and other NATO members, can be used as guidance with a critical judgment of their solutions and adjusted integration into Slovenian environment.

The complex modern security environment and the need for timely and quality information as well as efficient operation demand standardization of equipment and processes, and an effective decision-making process. Should the coordination of sea services and the comprehensive approach to safety and security on Slovenian sea represent the first two steps towards better efficiency and success, the integration of sea capabilities may be the end state providing the answer to modern security challenges at sea. The merging of operational structures and capabilities could lead to the reduction of vessels and hence to rational procurement and maintenance as well as harmonization of standards. On the other hand, we could afford more advanced vessels with higher capacity for continuous operation, also under difficult sea conditions during an increased security threat.

1. Androjna, A., 2010. Comprehensive Approach to Maritime Security of the Republic of Slovenia. Bilten SV 10/1, 192-201.

2. A cooperative Strategy for 21st Century Seapower, 2007. US Department for the Navy, US Marine Corps, US Coast Guard.

3. Booth, K., Wheeler, J. N., 2008. The Security Dilema-Fear, Cooperation, Thrust, Palgrave Macmillan, New York.

4. Časopis Seehafenbilanz z dne 10. junij 2011, št. 23. http:/www.verkehr.co.at, 17. 6. 2011.

5. Črnčec, D., 2010. Slovenija v geopolitičnem in geostrateškem okolju 21. stoletja, Bilten SV, junij 2010 - 12/št. 2, str. 55-56.

6. Geršak, B., 2008. Mednarodni vidiki zagotavljanja varnosti pomorskega prometa: Študija primera akvatorija Republike Slovenije, PŠŠ, Poljče.

7. Maritime Security: NATO and EU roles and co-ordination, http://www.nato-pa.int/default. asp?SHORTCUT=2087, 9. 2. 2011.

8. Podbregar, I., et.al, 2010. Informacija kot »bojna« podpora kriznemu odločanju, krizni komunikaciji in delovanju. Zavod za varnostne strategije pri Univerzi Maribor. Ljubljana.

9. Podbregar, I., 2011. Talka kampanjskega odnosa politike. Dnevnikov objektiv z dne 28. 5. 2011, str. 6.

10. Resolucija o splošnem dolgoročnem programu razvoja in opremljanja SV do leta 2025 , Uradni list RS, št. 99/10.

11. Resolucija o pomorski usmeritvi RS, Uradni list RS, št.10/91. 
12. Resolucija o nacionalnem programu razvoja pomorstva Republike Slovenije (ReNPRP), Uradni list RS, št. 87/10 z dne 3. 11. 2010.

13. Šteiner, A., 2010. Med tranzicijo in transformacijo. Bilten SV, junij 2010, št.12/2.

14. US JFCOM, 2008. The Comprehensive Approach: A Conceptual Framework for MNE5. Norfolk: USJFCOM.

15. Žabkar, A., 2011. Nova žarišča napetosti. Predavanje slušateljem 6. GŠŠ, Ljubljana.

16. Žnidar, I., 2011. Zaključna naloga na GŠS̆: Vpliv transformacije obrambnega resorja na zagotavljanje varnosti na Slovenskem morju, PŠŠ, Maribor.

17. http://www.stratfor.com/analysis/20110127-somali-piracy-annual-update (18. 3. 2011).

18. http://www.eunavforeu/ (27. 4. 2011).

19. http://www.manp.nato.int/operations/ActiveEndeavour/Endeavour.htm\#concept (16. 5. 2011). 